\title{
ASSESSING STUDENTS' LEVEL OF KNOWLEDGE IN PROFILE COURSES OF CHOSEN ECONOMIC STUDY PROGRAMMES AT THE FEM CULS PRAGUE
}

\begin{abstract}
To increase the educational attainment of the population is a priority that has arisen also from the pro-growth strategy of the European Union. In this regard, the quality of the teaching process in tertiary education and subsequent graduates' employability are paid substantial attention. However, the quality of knowledge and skills acquired and presented by the graduates on the labour market has not been observed so closely. The focus on quantitative aspects implies a significant risk of lowering qualitative standards. The present paper strives to analyze the development and structure of students' results within the framework of economic study programmes at the Faculty of Economics and Management CULS Prague in five consecutive academic years. Based on the analysis, the differences in study results, study skills and approaches are specified and compared between and among the individual study programmes and forms of study.
\end{abstract}

\section{Key Words}

Educational attainment of the population, forms of study, higher education, students' knowledge, study programmes, study results, success rate, universities

\section{Ivana Boháčková, Ivana Brožová}

Czech University of Life Sciences Prague brozovai@pef.czu.cz

\section{ARTICLE INFO}

Article type

Full research paper

doi: 10.7160/eriesj.2012.050304

Article history

Received: June 24, 2012

Received in revised form: September 25, 2012

Accepted: September 26, 2012

Available on-line: September 30, 2012

Boháčková, I. Brožová, I. (2012) "Assessing Students' Level of Knowledge

in Profile Courses of Choosen Economic Study Programmes at the FEM CULS",

Journal on Efficiency and Responsibility in Education and Science, Vol. 5,

No. 3, pp. 148-156, ISSN 1803-1617, [on-line] www.eriesjournal.com/_papers/article_175.pdf 


\section{Introduction}

In 2010, the EU summit of high member countries representatives set targets related to secondary and in particular tertiary education within the framework of "Supporting growth and jobs strategy". This strategy stems from the assumption that a highly skilled and creative population, i.e. high quality human capital, leads to economic development and prosperity. The 2020 education target stipulates that $40 \%$ of the age group $30-$ 34 should successfully complete higher education or equivalent studies (Strategic framework for education and training, 2012).

Most EU countries, including the Czech Republic, record the highest and ever-growing share of higher education students within the age group of 25-34. According to the Eurostat, there are only three countries where higher education attainment falls into the age group of 35-44 - these exceptions comprise Finland, Germany and also Austria where the two age groups are more or less equal.

Having the above facts in mind, higher education institutions, primarily colleges and universities, are at the centre of attention. The quality of teaching process in Bachelor and Master study programmes at particular universities and faculties is observed and discussed. A wide range of Czech authors, e.g. Mareš (1991), Šmelová (2002), Šabatová (2009), and foreign authors - Seldin (1990), Abari (2011) deal with the issue of teaching process quality and its assessment. At the same time, detailed analyses concerned with the relationship between the number of graduates and their employability have been carried out, sorted by the individual higher education institutions and also by the study programmes (Koutský, Zelenka 2011). Graduates' employability and career path on the labour market is influenced, besides other factors, by the teaching process quality. Nevertheless, it is quite hard to measure the knowledge and skills applied by students in practice at their workplaces (Mareš, 1990).

The educational attainment process involves not only schools (faculties, departments) and the quality of their pedagogues but at the same time the students themselves. Students' academic performance is influenced by a wide range of factors, above all by their study potential and willingness to acquire new knowledge and skills. The individual "talent" or "gift" can be already traced in the secondary school results (but not as a rule). The relationship between secondary school study results and subsequent university results has been dealt with e.g. by Kuncel (2001), Zwick (2006) or Rubešová (2009).

The above-mentioned studies infer that study results at university, especially in the first freshman year, are determined by the quality and demandedness of the secondary school. General study skills, self-study skills, self-organisation, ability to both team work and work independently, ability to search for and process information, to differentiate key pieces of information from the unimportant ones, capability of using common sense and logical thinking rather than pure memorizing - these constitute key prerequisites to good university performance. Current researches conducted at foreign universities prove that the quality of students, i.e. their study results, influences retroactively the quality of the educational process, e.g. Hassanbeigi (2011). Last but not least, factors related to acquiring new knowledge and skills also include motivation, socio-economic study conditions etc. 


\section{Materials and Methods}

The paper aims at several topical issues related to assessing the quality of higher education graduates and their level of knowledge. The results of FEM CULS students (Faculty of Economics and Management, Czech University of Life Sciences in Prague), namely the students of the Economics and Management study programme and Business and Administration study programme have been analyzed. Both study programmes are realized under both full-time and distance form. The analysis has been carried out on the example of two profile courses (both prerequisite for the final state examination): the "Agrarian Sector Economy" course taught within the framework of the Economics and Management study programme and the "Business Activity Assessment" course taught within the Business and Administration programme. The two courses are incorporated in the last year of study of the respective study programme; "Agrarian Sector Economy" in the Bachelor degree programme and "Business Activity Assessment" in the Master degree one. Both subjects are economy-related (substantial for the graduates' profile), identical in their form and scope and also identical in view of the course requirements and grading system. As far as the form and scope of teaching are concerned, both courses entail lectures and seminars. Full-time study programmes are given a 90-minute lecture per week and a 90-minute seminar every two weeks. Distance study programmes require a substantial load of self-study, accompanied by 12 hours of face-to-face sessions per term (Curricula of the FEM 2009/2010, 2009).
The analysis was supposed to answer the following questions:

- Can we assume that FEM students (regardless to the form of study and study programme) record a low rate of high grades (excellent results)? In other words, is the level of knowledge acquired by the graduates in these profile courses low?

- Are there any significant differences in study results between and among the individual study programmes and forms of study?

- Do students record better results while retaking the examination (thanks to more studious preparation)?

- Have the study results been generally deteriorating?

- Which factors influence the study results recorded?

The following methodical approach has been adopted in order to analyze students' level of knowledge:

- The results in five consecutive academic years were recorded and analyzed, involving the the total of 2,072 (two thousand and seventy-two) full-time students and 1,563 (one thousand five hundred and sixty-three) distance students.

- Only those students who actually took part in the examination were included in the sample. It means that the sample did not integrate those students who registered for the examination but finally did not turn out. In accordance with the Study and Examination Rules of the Czech University of Life Sciences in Prague of 15th July 2010, these students are classified with a "fail" grade. Due to their absence at the examination, these students were not able to demonstrate their knowledge. If we included them in the sample analyzed, i.e. calculate the "fail" grades, the results would be biased. 
- The results were recorded on the basis of the grade attained (excellent, very good, good and fail) at all examination sessions the students took; i.e. if a student failed at the first session, his/her performance at the second session (i.e. first retake), or as the case may be at the third session (i.e. second retake) were monitored.

- In order to determine an average result for the individual examination sessions and also for the whole examination period, the weighted arithmetic mean has been used while the value corresponded to the grade attained and the weigh equalled to the total of students who achieved the respective grade.

- Elementary analytical methods (horizontal and vertical analysis) and comparison have been employed. The study results have been compared between and among the individual study programmes (Economics and Management, Business and Administration), the two years of study $\left(3^{\text {rd }}\right.$ year of the Bachelor programme and $2^{\text {nd }}$ year of the Master degree programme) and last but not least both forms of study (full-time, distance).

As far as the software is concerned, the MS Excel, version 2007 has been used for calculations.

\section{Results and Discussion}

The following outcomes stemmed from the analysis of the examination results attained in the two aforementioned courses:

- As we can see from Table 1, the grades attained in both forms of study (full-time and distance) and courses (Agrarian Sector Economy, Business Activity Assessment) are far from being satisfactory. As for the "Agrarian Sector Economy“ course, the frequency of „excellent" grade in the whole examination period (i.e. for all three eligible sessions) ranges from $0.48 \%$ to $7.49 \%$ in the distance study programme, and from $4.82 \%$ to $8.90 \%$ in the respective full-time one. The "Business Activity Assessment" course showed ,excellent" grades in the interval from $0 \%$ to $21.09 \%$ in the distance form while the percentage recorded in the full-time form averaged between $1.07 \%$ and $12.08 \%$. On the other side of the scale, we can observe that the frequency of failures is high. As for the "Agrarian Sector Economy" course, the distance form failures ranged from $7.87 \%$ to $26.99 \%$ and the full-time ones from $38.66 \%$ to $49.05 \%$. The „Business Activity Assessment" course recorded the failure percentage between $22.66 \%$ and $57.53 \%$ in the distance study form and from $24.15 \%$ to $47.43 \%$ in the full-time one. It clearly stems from the analysis that the "core" of the results attained at both examinations is the "good" passing grade. There are two different reasonings to be raised at this point. Firstly, we can suppose that students achieving worse results are not sufficiently devoted to the preparation even if they do evince the skills and potential needed. These students' priority is to pass the examination regardless of the grade and therefore to be content with a worse result. On the other hand, there are students who do a very thorough preparation but their general learning potential, capabilities or "talent" do not allow them to meet the requirements and achieve a better result. 


\begin{tabular}{|c|c|c|c|c|c|c|c|c|c|c|c|c|c|c|c|c|c|c|c|c|}
\hline \multirow{3}{*}{$\begin{array}{l}\text { Agrarian } \\
\text { Sector } \\
\text { Economy } \\
\text { Distance studies }\end{array}$} & \multicolumn{4}{|c|}{$2006 / 2007$} & \multicolumn{4}{|c|}{$2007 / 2008$} & \multicolumn{4}{|c|}{$2008 / 2009$} & \multicolumn{4}{|c|}{$2009 / 2010$} & \multicolumn{4}{|c|}{$2010 / 2011$} \\
\hline & \multicolumn{3}{|c|}{ Session } & \multirow[b]{2}{*}{$\Sigma$} & \multicolumn{3}{|c|}{ Session } & \multirow[b]{2}{*}{$\Sigma$} & \multicolumn{3}{|c|}{ Session } & \multirow[b]{2}{*}{$\Sigma$} & \multicolumn{3}{|c|}{ Session } & \multirow[b]{2}{*}{$\Sigma$} & \multicolumn{3}{|c|}{ Session } & \multirow[b]{2}{*}{$\Sigma$} \\
\hline & 1st & 2nd & 3 rd & & 1st & 2nd & 3 rd & & 1st & 2nd & 3 rd & & 1st & 2nd & 3 rd & & 1st & 2nd & 3 rd & \\
\hline Excellent (\%) & 3.74 & 1.72 & 11.36 & 7.49 & 3.85 & 2.50 & 2.50 & 5.50 & 0 & 0.96 & 0 & 0.48 & 0.62 & 1.04 & 4.00 & 2.45 & 2.36 & 3.64 & 13.04 & 6.30 \\
\hline Very good (\%) & 10.16 & 14.66 & 22.73 & 24.60 & 15.93 & 12.50 & 20.00 & 25.82 & 11.43 & 3.85 & 6.52 & 14.76 & 5.52 & 3.13 & 4.00 & 8.59 & 11.81 & 16.36 & 39.13 & 25.98 \\
\hline Good (\%) & 17.65 & 31.90 & 34.09 & 45.45 & 25.82 & 20.00 & 50.00 & 46.60 & 34.29 & 38.46 & 60.87 & 66.66 & 28.83 & 33.33 & 44.00 & 61.97 & 37.01 & 36.36 & 39.13 & 59.85 \\
\hline Fail (\%) & 68.45 & 51.72 & 31.82 & 22.46 & 54.40 & 65.00 & 27.50 & 23.08 & 54.28 & 56.73 & 32.61 & 18.10 & 65.03 & 62.50 & 48.00 & 26.99 & 48.82 & 43.64 & 8.70 & 7.87 \\
\hline \multirow{3}{*}{$\begin{array}{l}\text { Agrarian Sector } \\
\text { Economy } \\
\text { Full-time studies }\end{array}$} & \multicolumn{4}{|c|}{$2006 / 2007$} & \multicolumn{4}{|c|}{$2007 / 2008$} & \multicolumn{4}{|c|}{$2008 / 2009$} & \multicolumn{4}{|c|}{$2009 / 2010$} & \multicolumn{4}{|c|}{$2010 / 2011$} \\
\hline & \multicolumn{3}{|c|}{ Session } & & \multicolumn{3}{|c|}{ Session } & & \multicolumn{3}{|c|}{ Session } & & & Sessio & & & & Session & & \\
\hline & 1. & 2. & 3. & $\Sigma$ & 1. & 2. & 3. & $\Sigma$ & 1. & 2. & 3. & $\Sigma$ & 1. & 2. & 3. & $\Sigma$ & 1. & 2. & 3. & $\Sigma$ \\
\hline Excellent(\%) & 7.75 & 13.89 & 10.00 & 8.69 & 9.82 & 7.92 & 7.14 & 8.90 & 9.40 & 4.50 & 5.49 & 7.12 & 7.03 & 4.24 & 2.35 & 5.36 & 7.32 & 2.88 & 2.17 & 4.82 \\
\hline Very good (\%) & 25.25 & 26.39 & 28.00 & 23.76 & 18.41 & 23.27 & 21.43 & 20.38 & 17.55 & 13.51 & 18.68 & 16.30 & 14.38 & 18.22 & 14.12 & 15.77 & 14.29 & 18.52 & 25.00 & 17.52 \\
\hline Good (\%) & 23.00 & 46.53 & 54.00 & 28.89 & 22.08 & 27.72 & 37.50 & 25.51 & 25.71 & 27.48 & 34.07 & 27.53 & 24.92 & 30.51 & 57.65 & 31.39 & 21.95 & 34.57 & 52.17 & 31.36 \\
\hline Fail (\%) & 44.00 & 13.19 & 8.00 & 38.66 & 49.69 & 41.09 & 33.93 & 45.21 & 47.34 & 54.51 & 41.76 & 49.05 & 53.67 & 47.03 & 25.88 & 47.48 & 56.44 & 44.03 & 20.66 & 46.30 \\
\hline Business Activity & & 200 & $/ 2007$ & & & 200 & 2008 & & & 2008 & 2009 & & & 200 & 2010 & & & 2010 & 2011 & \\
\hline Assessment & & Sessio & & & & Sessior & & & & Session & & & & Sessio & & & & Session & & \\
\hline Distance studies & 1. & 2. & 3. & $\Sigma$ & 1. & 2. & 3. & $\Sigma$ & 1. & 2. & 3. & $\Sigma$ & 1. & 2. & 3. & $\Sigma$ & 1. & 2. & 3. & $\Sigma$ \\
\hline Excellent $(\%)$ & 23.60 & 10.34 & 30.00 & 21.09 & 4.05 & 11.11 & 16.67 & 6.54 & 1.28 & 2.22 & 5.56 & 2.13 & 3.53 & 0.00 & 0.00 & 2.06 & 0.00 & 0.00 & 0.00 & 0.00 \\
\hline Very good (\%) & 19.97 & 17.24 & 30.00 & 18.75 & 10.81 & 11.11 & 16.67 & 11.21 & 6.41 & 13.33 & 22.22 & 10.64 & 2.35 & 11.36 & 17.62 & 6.85 & 7.00 & 22.22 & 21.05 & 13.74 \\
\hline Good (\%) & 37.08 & 37.94 & 40.00 & 37.50 & 45.95 & 48.15 & 50.00 & 46.73 & 34.62 & 33.33 & 61.11 & 37.59 & 34.12 & 31.82 & 35.29 & 33.56 & 22.00 & 44.44 & 52.63 & 32.96 \\
\hline Fail (\%) & 21.35 & 34.48 & 0.00 & 22.66 & 39.19 & 29.63 & 16.66 & 35.52 & 57.69 & 51.12 & 11.11 & 49.64 & 60.00 & 56.82 & 47.09 & 57.53 & 71.00 & 33.34 & 26.32 & 53.30 \\
\hline Business Activity & & 200 & $/ 2007$ & & & 200 & 2008 & & & 2008 & 2009 & & & 200 & 2010 & & & 2010 & 2011 & \\
\hline Assessment & & Sessior & & & & Sessior & & & & Session & & & & Sessio & & & & Session & & \\
\hline Full-time studies & 1. & 2. & 3. & $\Sigma$ & 1. & 2. & 3. & $\Sigma$ & 1. & 2. & 3. & $\Sigma$ & 1. & \begin{tabular}{|l|}
2. \\
\end{tabular} & 3. & $\Sigma$ & 1. & 2. & 3. & $\Sigma$ \\
\hline Excellent $(\%)$ & 15.19 & 2.86 & 0.00 & 12.08 & 1.15 & 7.46 & 8.34 & 3.16 & 3.48 & 2.50 & 4.16 & 3.29 & 0.75 & 1.08 & 6.67 & 1.07 & 4.91 & 1.85 & 0.00 & 3.75 \\
\hline Very good (\%) & 24.68 & 11.43 & 50.00 & 24.15 & 8.62 & 16.42 & 41.66 & 12.25 & 22.61 & 22.50 & 12.50 & 21.86 & 11.32 & 27.96 & 46.67 & 16.89 & 18.59 & 9.26 & 32.35 & 17.33 \\
\hline Good (\%) & 37.90 & 42.86 & 50.00 & 39.62 & 32.76 & 47.76 & 41.66 & 37.16 & 34.78 & 43.75 & 70.84 & 39.52 & 48.68 & 44.08 & 26.66 & 46.65 & 35.44 & 52.78 & 52.94 & 41.22 \\
\hline Fail (\%) & 22.23 & 42.85 & 0.00 & 24.15 & 57.47 & 28.36 & 8.34 & 47.43 & 39.13 & 31.25 & 12.50 & 35.33 & 39.25 & 26.88 & 20.00 & 35.39 & 41.06 & 36.11 & 14.71 & 37.70 \\
\hline
\end{tabular}

Table 1: Structure of the examination results (grades) 
- When observing the grades in the order of individual examination sessions, we can say that the highest rate of "fail" (see Fig. 1 and Fig. 2) is recorded at the first attempt. The number of students who fail the examination at this stage is very high. In the sample, one of the academic years even saw a failure rate of $71 \%$ (Business Activity Assessment - distance form, academic year 2010/2011). As the students themselves admitted in an anonymous opinion poll, they either decided to "come and give it a try" or underestimated the preparation and therefore failed. After the first failure, some students give up and do not even keep on trying; the others register for the retake sessions. However, a high percentage of "fail" grades also occurs at the second examination session (i.e. first retake). Furthermore, the results at the third attempt (i.e. second retake) shown in Table 1 are again far from reaching a high success rate. This is quite astounding as the motivation to pass the examinations in question should be very high (in case of failure, a student has to retake one year, cannot register for the final state examination and, in the worst possible case, can even be offloaded from study). Taking the above facts into account, it can be assumed that these failing students are simply not capable of efficient preparation. This is quite obvious at the oral examination where these students merely reproduce without understanding the point or the problem. Moreover, it can be observed that the students are not able to use specialist literature/resources independently - they memorize the content of lectures or textbooks and then "reproduce" it at the examination.

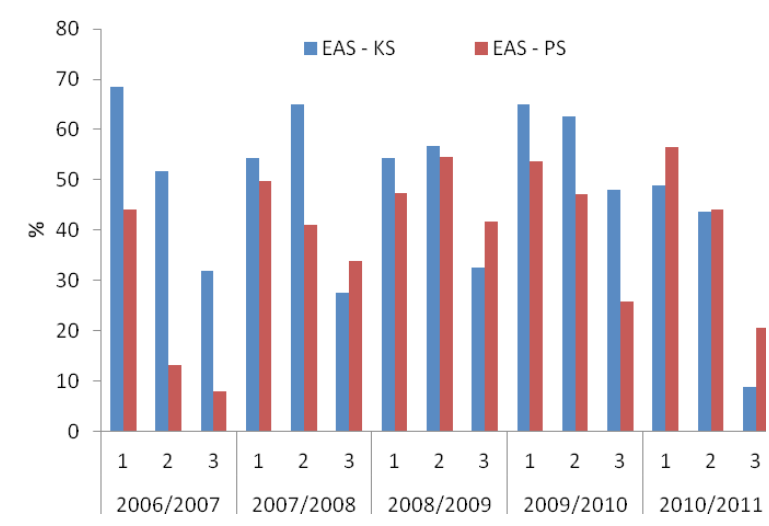

Figure 1: Overview of "fail" grades at the individual examination sessions of the Agrarian Sector Economy course (distance form shown in blue, full-time in red)

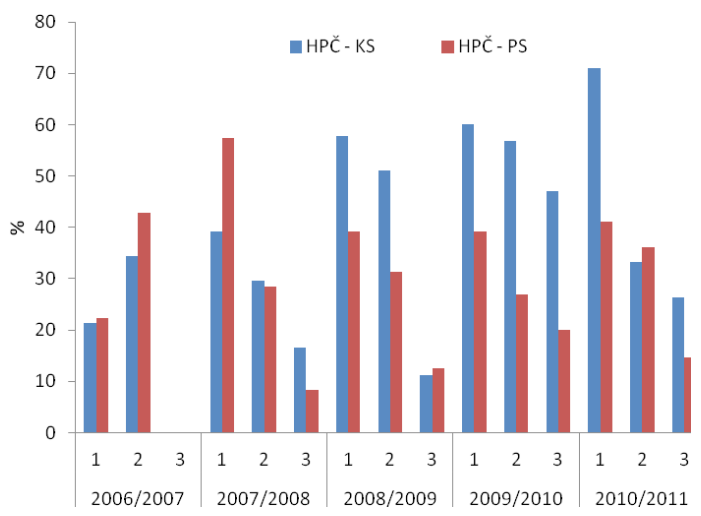

Figure 2: Overview of "fail" grades at the individual examination sessions of the Business Activity Assessment course (distance form shown in blue, full-time in red) 
- As we can see from the five-year interval shown in Fig. 1 and Fig. 2, there are some differences in the average study results attained not only between the two study programmes but also between the two forms of study. The results in the distance form were fluctuating, however, the overall results have been deteriorating in both subjects surveyed (Agrarian Sector Economy, Business Activity Assessment). The results in the full-time form were also very volatile nevertheless, compared to the distance form, they were generally more positive in some years. Anyway, also the average results recorded in the full-time form of study have been generally deteriorating. This very likely reflects recent situation when more and more students who lack higher education prerequisites (knowledge, skills, motivation to study) are admitted to universities. On the other hand, there is undoubtedly a certain share of students who have the potential and capabilities to perform better but employ it more in various after-school or extra-curricular activities.

- It can also be stated that the more students in the year, the worse average study results attained. For instance, in the academic year 2006/2007, the 158 Business and Administration students (full-time) recorded the average grade of 2.76 in the Business Activity Assessment course whereas in 2010/2011, 285 students recorded the average result of 3.13. Within the Economics and Management study programme (full-time), the 410 students of the Agrarian Sector Economy course attained the average grade of 3.26 in the academic year 2008/2009. However, in 2010/2011, 379 students recorded the average of 3.19. This is indicative of the fact that the quantitative aspect of the entrance examination procedure outweighed the qualitative standards of applicants.

\begin{tabular}{|c|c|c|c|c|c|c|c|c|}
\hline & \multicolumn{9}{|c|}{ Agrarian Sector Economy } \\
\cline { 2 - 7 } Academic year & \multicolumn{4}{|c|}{ Full-time studies } & \multicolumn{5}{c|}{ Distance studies } \\
\cline { 2 - 7 } & \multicolumn{3}{|c|}{ session } & total & \multicolumn{3}{c|}{ session } & total \\
\cline { 2 - 7 } & 1st & 2nd & 3rd & average & 1st & 2nd & 3rd & average \\
\hline $\mathbf{2 0 0 6 / 2 0 0 7}$ & 3.03 & 2.59 & 2.60 & 2.89 & 3.51 & 3.34 & 2.86 & 3.37 \\
\hline $\mathbf{2 0 0 7 / 2 0 0 8}$ & 3.12 & 3.02 & 2.98 & 3.07 & 3.31 & 3.48 & 3.03 & 3.32 \\
\hline $\mathbf{2 0 0 8 / 2 0 0 9}$ & 3.27 & 3.28 & 3.14 & 3.26 & 3.43 & 3.51 & 3.26 & 3.43 \\
\hline $\mathbf{2 0 0 9 / 2 0 1 0}$ & 3.25 & 3.20 & 3.07 & 3.21 & 3.58 & 3.57 & 3.36 & 3.54 \\
\hline $\mathbf{2 0 1 0 / 2 0 1 1}$ & 3.28 & 3.20 & 2.91 & 3.19 & 3.32 & 3.20 & 2.43 & 2.19 \\
\hline
\end{tabular}

Table 2: Examination results in relation to the individual sessions (attempts) - Agrarian Sector Economy, Bachelor degree, Economics and Management study programme

\begin{tabular}{|c|c|c|c|c|c|c|c|c|}
\hline \multirow{4}{*}{ Academic year } & \multicolumn{8}{|c|}{ Business Activity Assessment } \\
\hline & \multicolumn{4}{|c|}{ Full-time studies } & \multicolumn{4}{|c|}{ Distance studies } \\
\hline & \multicolumn{3}{|c|}{ session } & \multirow{2}{*}{$\begin{array}{c}\text { total } \\
\text { average }\end{array}$} & \multicolumn{3}{|c|}{ session } & \multirow{2}{*}{$\begin{array}{c}\text { total } \\
\text { average }\end{array}$} \\
\hline & 1st & 2nd & 3rd & & $1 \mathrm{st}$ & 2nd & $3 \mathrm{rd}$ & \\
\hline $2006 / 2007$ & 2.67 & 3.26 & 2.50 & 2.76 & 2.56 & 2.96 & 2.10 & 2.62 \\
\hline $2007 / 2008$ & 3.47 & 2.97 & 2.50 & 3.29 & 3.20 & 2.96 & 2.67 & 3.11 \\
\hline $2008 / 2009$ & 3.10 & 3.04 & 2.92 & 3.07 & 3.49 & 3.33 & 2.78 & 3.34 \\
\hline $2009 / 2010$ & 3.26 & 2.97 & 2.60 & 3.16 & 3.51 & 3.45 & 3.29 & 3.46 \\
\hline $2010 / 2011$ & 3.13 & 3.23 & 2.82 & 3.13 & 3.64 & 3.11 & 3.05 & 3.39 \\
\hline
\end{tabular}

Table 3: Examination results in relation to the individual sessions (attempts) - Business Activity Assessment, Master degree, Business and Administration study programme 


\section{Conclusion}

Based on the analysis of study results attained by 3,635 (three thousand six hundred and thirty-five) students at the examinations of chosen FEM core subjects, the following conclusions can be made:

- Can we assume that the level of knowledge acquired by the graduates in the core courses is low? This question can be answered quite decidedly - the study results attained do not prove satisfactory mastering of core economic subjects. Even if only two of these courses have been analyzed, similar results can be expected also in other subjects. Based on the long-term pedagogical experience, we can say that not all students with excellent grades become excellent professionals and vice versa, an average student recording average or even poor study results can become a successful specialist in the field. However, this cannot be generalized. As we have already mentioned, there are two main reasons behind poor study results. The students either prefer a mere passing of the examination regardless of the result (i.e. grade) or lack the respective higher education prerequisites and therefore should not be admitted to the university at all. As stated in the introduction to this paper, the European strategy is to increase the share of higher education graduates in the age group 25-34 to $40 \%$. Nevertheless, this quantitative expansion in tertiary education sector could lead to a potentially risky situation (Koutský, Zelenka, 2011) when the percentage of university graduates in the population will grow but not hand in hand with the quality knowledge. This was proven by analyzing the sample of FEM CULS students. While the number of students has been growing, the study results attained have been deteriorating at the same time. It has to be mentioned in this connection that the quality of students does not result only from the quality of the teaching process; the interdependence between the quality teaching process and students'/graduates' performance is not so straightforward (which is quite a common simplification of the problem).

- Even if one logically assumes that students who fail the examination would prepare more studiously for the retake session, this is not often true. On the contrary, $3^{\text {rd }}$ year students of the distance Bachelor degree programme recorded even worse results (from a viewpoint of "fail" grades frequency) at the first retake of the "Agrarian Sector Economy" examination. This paradox sometimes occurred also in the full-time form of study. The situation in the "Business Activity Assessment" course, taught in the second year of the Master degree programme, is, generally speaking, a little more positive since the students already "keep their eyes on the diploma" and are therefore more motivated. However, also the results in some years disproved this logical assumption.

- As for whether there are any significant differences in study results between the two forms of study, we can say that these differences certainly exist. The results attained by the students of distance study are generally worse than those recorded by full-time students within both Bachelor and Master programme. There are likely to be more reasons for this structure of study results. Above all, the timedemandedness of distance study that mainly arises from the fact that these students are supposed to balance their occupational duties, school duties and often also family commitments. Furthermore, some students are forced to acquire a university degree/higher qualification by their employers (in order to retain their current position) and 
would not otherwise evince strong inner motivation to study. Another decisive factor (having a substantial impact) lies in the fact that distance forms of study are actually based on self-study. However, most students "cannot" study independently; on their own. They usually prefer memorizing textbooks or other resources and do not use other references and specialist literature. This then results in "reproducing" the texts without really understanding and grasping the essence of the problem, the context and other relations.

\section{Acknowledgements}

The findings presented in the paper were obtained as a result of the Research Program titled "Economy of the Czech Agriculture Resources and Their Efficient Use within the Framework of the Multifunctional Agri-food Systems" of the Czech Ministry of Education, Youth and Sports number VZ MSM 6046070906.

\section{References}

Abari, A. A. F., Yarmohammadian, M. H., Esteki, M. (2011) "Assessment of quality of education a non-governmental university via SERVQUAL model“, Procedia Social and Behavioral Science, vol. 15, pp. 2299-2304. http://dx.doi. org/10.1016/j.sbspro.2011.04.097

Hassanbeigi, A. et al (2011) „The relationship between study skills and academic performance of university students", Procedia Social Behavioral Science, vol. 30, pp. 1416-1424. http://dx.doi.org/10.1016/j.sbspro.2011.10.276

Koutský, J., Zelenka, M. (2011) „Postavení vysokoškoláků a uplatnění absolventů vysokých škol na pracovním trhu“, 6. výroční zpráva SVP, Praha [online], http:// www.strediskovzdelavacipolitiky.info/

Kuncel, N. R., Hezlett, S. A., Ones, D. S. (2001) „A Comprehensive meta - analysis of the predictive validity of the graduates record examination: Implications for graduate student selection and performance“" Psychological Bulletin, vol. 127, No. 1, pp. 102181. http://dx.doi.org/10.1037/0033-2909.127.1.162

Mareš, J. (1991) „Studentské posuzování jako jedna z metod hodnocení vysokoškolské výuky“, Praha SNP.

Mareš, J. a kol. (1990) „Srovnání očekávaného a reálného výkonu studenta u zkoušky", VŠ, č. 8, pp. 353-363.

„Strategic framework for education and training, European Commission 2012, [online], http://ec.europa.eu/education/ lifelong-learning-policy/framework_en.htm

Rubešová, J. (2009) „Souvisí úspěšnost studia na VŠ se středoškolským prospěchem?", Pedagogická orientace 3, pp. 89-103.

Seldin, P. et al (1990) „How administrators can improve teaching" Josuy-Bass, San Francisco.

„Studijní a zkušební řád České zemědělské univerzity v Praze ze dne 15. července 2010", [online], http://dl.webcore.czu.cz

"Studijní plány PEF pro akademický rok 2009/2010“ (2009), Česká zemědělská univerzita v Praze, Provozně ekonomická fakulta, 107 s. ISBN 978-80-213-1876-2.

Šabatová, I. (2009) „Hodnocení efektivnosti výuky“ [online], http://theses.cz/id/62vmsx/lang=en,fur/=/id/62vmsx

Šmelová, E. (2002) „Hodnocení výuky vysokoškolskými studenty" [online], http://pedagog.upol.cz/epod

Zwick R. (2006) „Higher education admissions testing“, 4th ed. Educational measurement, ACE/Praeger series on higher education, pp. 647-679. 